\title{
RELATIVE COMPETITIVENESS BETWEEN MAIZE HYBRIDS AND WILD POINSETTIA $^{1}$
}

\author{
LEANDRO GALON $^{2}$, RICARDO LUIS GABIATTI ${ }^{2}$, FELIPE JOSÉ MENIN BASSO ${ }^{3}$, ANDRÉ LUIZ RADÜNZ ${ }^{4}$, \\ FRANCISCO WILSON REICHERT JÚNIOR ${ }^{2}$, RENAN CARLOS FIABANI ${ }^{3}$
}

\begin{abstract}
Maize is one of the main cereals cultivated worldwide and wild poinsettia is among the weeds that cause damage in grain production. The objective of this study was to evaluate the relative competitive ability of maize hybrids in the presence of a wild poinsettia biotype through experiments in replacement series. In preliminary experiments, it was determined the plant population in which the dry mass becomes constant. For the maize hybrids 'Agroeste', 'Morgan', 'Nidera', and 'Velox', as well as the wild poinsettia, the population was 20 individuals vase ${ }^{-1}$. Subsequently, experiments were carried out in replacement series in different combinations of species that varied the relative proportions (100:0, 75:25, 50:50, 25:75, and 0:100\%). The analysis of the species' competitiveness was carried out using diagrams applied to the replacement experiments and by the relative competitiveness indexes. The height (PH), chlorophyll index (CI), leaf area (LA), and the shoot dry mass (DM) of the plants were evaluated 50 days after emergence. There was competition between the maize hybrids and the wild poinsettia; both were negatively affected, regardless of the proportion of plants, causing reductions in the species' PH, CI, LA, and DM. The competition between maize and wild poinsettia occurs for the same resources in the environment, and interspecific competition caused greater damage to maize and wild poinsettia than intraspecific competition. In general, it was observed that only the hybrids 'Nidera' and 'Velox' were more competitive than the wild poinsettia.
\end{abstract}

keywords: Zea mays. Euphorbia heterophylla. Competitive interaction.

\section{COMPETITIVIDADE RELATIVA ENTRE HÍBRIDOS DE MILHO E BIÓTIPO DE LEITEIRO}

RESUMO - O milho é um dos principais cereais cultivados no mundo e o leiteiro aparece entre as plantas daninhas que causam prejuízos na produção de grãos. Objetivou-se com o trabalho avaliar a habilidade competitiva relativa de híbridos de milho na presença de um biótipo de leiteiro, por meio de experimentos em série de substituição. Em experimentos preliminares, determinou-se a população de plantas em que a massa seca se torna constante. Tanto para os híbridos de milho Agroeste, Morgan, Nidera e Velox, quanto para o leiteiro, a população foi de 20 indivíduos vaso ${ }^{-1}$. Posteriormente foram instalados experimentos conduzidos em série de substituição, nas diferentes combinações das espécies, variando-se as proporções relativas (100:0, 75:25, 50:50, 25:75 e 0:100\%). A análise da competitividade das espécies foi efetuada por meio de diagramas aplicados a experimentos substitutivos e pelos índices de competitividade relativa. A estatura (EP), índice de clorofila (IC), área foliar (AF) e a massa seca da parte aérea (MS) das plantas foram avaliadas aos 50 dias após a emergência. Ocorre competição entre os híbridos de milho com o leiteiro, sendo ambos afetados negativamente, independentemente da proporção de plantas, provocando reduções nas EP, IC, AF e MS das espécies. A competição entre o milho e leiteiro ocorre basicamente pelos mesmos recursos do meio. A competição interespecífica ocasiona maiores prejuízos ao milho e o leiteiro do que a competição intraespecífica. De modo geral observou-se que apenas os híbridos Nidera e Velox foram mais competitivos do que o leiteiro.

Palavras-chave: Zea mays. Euphorbia heterophylla. Interação competitiva.

\footnotetext{
${ }^{*}$ Corresponding author

${ }^{1}$ Received for publication in 04/06/2020; accepted in 01/22/2021.

Paper extracted from the Sustainable Management of Agricultural Systems Research Group.

${ }^{2}$ Graduate Program in Environmental Science and Tecnology, Universidade Federal da Fronteira Sul, Campus Erechim, RS, Brazil; leandro.galon@uffs.edu.br - ORCID: 0000-0002-1819-462X, ricardo.gabiatti@edu.sesisc.org.br - ORCID: 0000-0002-9873-7443, chicowrj@gmail.com - ORCID: 0000-0002-4501-898X.

${ }^{3}$ Department of Agronomy, Universidade Federal da Fronteira Sul, Erechim, RS, Brazil; bepifelipe@gmail.com - ORCID: 0000-00029317-7002, renanfiabane@gmail.com - ORCID: 0000-0002-8614-8895.

${ }^{4}$ Department of Agronomy, Universidade Federal da Fronteira Sul, Chapecó, SC, Brazil; andre.radunz@uffs.edu.br- ORCID: 0000-00022397-011X.
} 


\section{INTRODUCTION}

Weeds compete with maize for water, light, and nutrients, making it difficult to manage crops, pests, and diseases, or they may even release allelopathic substances that interfere with the growth and development of the crop (MORAES et al., 2013; FRANDOLOSO et al., 2019; GALON et al., 2021). Losses caused by weeds can reduce maize production by up to $70 \%$ and reduce the quality of the product if no management is adopted to control these species (MORAES et al., 2013; FARIA; BARROS; TUFFI SANTOS, 2014; GALON et al., 2019).

In this context, the wild poinsettia (Euphorbia heterophylla), a species widely found in crops, stands out as one of the weeds with the highest potential for damage, especially for its high competitive ability, high capacity for shading and seed production, and due to its multiple resistance mechanisms, which make it difficult to control using acetolactate synthase-ALS, protoporphyrinogen oxidase-PROTOX and 5 enolpyruvylshikimate-3phosphate synthase-EPSPs-inhibiting herbicides (TREZZI et al., 2006; VARGAS et al., 2013; WANDSCHEER; RIZZARDI; REICHERT, 2013; AGOSTINETTO et al., 2017; HEAP, 2020). The herbicides with the aforementioned mechanisms of action are the ones used most in maize for the control of wild poinsettia and other species. Thus, knowing the competitive ability of maize hybrids relative to the weeds becomes an important tool for the development of management strategies or even the adoption of integrated weed management.

In crops, the population of cultivated plants is generally constant, whereas the population of weeds varies according to the soil seed bank, with environmental and management conditions that alter the level of infestation and consequent the competitiveness of species (AGOSTINETTO et al., 2013; WANDSCHEER; RIZZARDI; REICHERT, 2013; FRANDOLOSO et al., 2019; GALON et al., 2021). Thus, in competition studies, it is not enough to evaluate only the plant population in the competitive process, but also the influence of variation in the proportions between species (BIANCHI; FLECK; LAMEGO, 2006; FLECK et al., 2008; AGOSTINETTO et al., 2013).

For the study of the competitive interactions between the crop and weeds, experimental designs and appropriate analysis methods are required, with conventional replacement series experiments being the most used to clarify such relationships (AGOSTINETTO et al., 2013; WANDSCHEER; RIZZARDI; REICHERT, 2013; FORTE et al., 2017; GALON et al., 2021). In these experiments, crops generally achieve greater competitive ability than weeds. In the field, the weed's effect on the crop is mainly due to the level of infestation and not to its individual competitive ability (FLECK et al., 2008).
However, when there is competition between individuals of the same genus and/or species, the competitive advantage of the culture may be altered, since both explore the same ecological niche.

Thus, studies that show the variation in the proportion between weeds and the crop become relevant to develop management strategies, based on the possibility of defining the characteristics that give the crops greater competitive ability (FLECK et al., 2008; AGOSTINETTO et al., 2013; WANDSCHEER; RIZZARDI; REICHERT, 2013; FORTE et al., 2017).

The work hypothesizes that maize hybrids present differentiation in their ability to compete with the wild poinsettia. Therefore, the objective of this work was to evaluate the relative competitive ability of maize hybrids in the presence of wild poinsettia, through replacement series experiments.

\section{MATERIAL AND METHODS}

Nine experiments were installed in a greenhouse at the Federal University of Fronteira Sul (UFFS), Campus Erechim, RS, between November 2016 and February 2017. The experimental units consisted of plastic vessels with a capacity of $8 \mathrm{dm}^{3}$, filled with soil from an agricultural area, characterized as latosol (EMBRAPA, 2013). The correction of $\mathrm{pH}$ and soil fertility was carried out according to the technical recommendations for the cultivation of grain corn and based on physicalchemical analysis (SILVA et al., 2016). The chemical and physical characteristics of the soil were: $\mathrm{pH} 4.8 ; \mathrm{OM}=3.5 \% ; \mathrm{P}=4.0 \mathrm{mg} \mathrm{dm}^{-3} ; \mathrm{K}=$ $117.0 \mathrm{mg} \mathrm{dm}{ }^{-3} ; \mathrm{Al}^{3+}=0.6$ cmolc $\mathrm{dm}^{-3} ; \mathrm{Ca}^{2+}=4.7$ cmolc $\mathrm{dm}^{-3} ; \mathrm{Mg}^{2+}=1.8$ cmolc $\mathrm{dm}^{-3} ; \operatorname{CEC}(\mathrm{t})=7.4$ cmolc $\mathrm{dm}^{-3} ; \operatorname{CEC}(\mathrm{TpH}=7.0)=16.5$ cmolc $\mathrm{dm}^{-3}$;

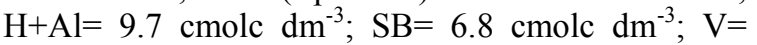
$41 \%$ e Clay $=60 \%$.

The experimental design adopted in all experiments was randomized blocks, with four replications. The tested competitors included the maize hybrids Agroeste (AS 1551 PRO 2), Morgan (MG 300 PW), Nidera (NS 92 PRO), Syngenta (Velox TL) that competed with the wild poinsettia (Euphorbia heterophylla). The main characteristics of the maize hybrids tested in the experiments are shown in Table 1.

As a preliminary, both for maize hybrids and wild poinsettia, in monoculture, five experiments were carried out in order to estimate the population of plants in which the final dry mass production becomes constant. For this, populations of 1, 2, 4, 8, $16,24,32,40,48,56$ e 64 plants pot $^{-1}$ (equivalent to $25,49,98,196,392,587,784,980,1.176,1.372 \mathrm{e}$ 1.568 plants $\left.\mathrm{m}^{-2}\right)$. At 50 days after the emergence of the species, four replicates per treatment were collected to determine the dry mass of the shoot part (DM) of the maize and/or wild poinsettia, this being 
quantified by weighing, after being dried in oven with forced air circulation at a temperature of $65 \pm$ $5^{\circ} \mathrm{C}$ until it reaches constant mass. Through the average DM values of the species, constant DM production was obtained with populations of 20 plants pot $^{-1}$, for all maize hybrids and/or the wild poinsettia biotype which was equivalent to 463 plants $\mathrm{m}^{-2}$ (data not shown).

Table 1. Genetic characteristics of the hybrids used in the study. UFFS, Campus Erechim, 2016/17.

\begin{tabular}{cccc}
\hline Company & Pedigree & Genotype & Cycle and biotechnology \\
\hline Agroeste & AS 1551 PRO2 & Híbrido Simples & Super-early and biotechnology VT PRO 2 \\
Morgan & MG 300 PW & Híbrido Simples & Super-early and biotechnology PowerCore \\
Nidera & NS 92 PRO & Híbrido Simples & Early and biotechnology VT PRO \\
Syngenta & Velox TL & Híbrido Simples & Early and biotechnology TL \\
\hline
\end{tabular}

The replacement series experiments consisted of five treatments formed by the relative proportions (\%) maize: wild poinsettia of 100:0, 75:25, 50:50, $25: 75$ and $0: 100$, which was equivalent to $20: 0,15: 5$, 10:10, 5:15 e 0:20 plants pot ${ }^{-1}$. Four experiments were installed to evaluate the competitive ability of the maize hybrids Agroeste (AS 1551 PRO 2), Morgan (MG 300 PW), Nidera (NS 92 PRO) and Syngenta (Velox TL) with wild poinsettia plants, both conducted in replacement series, in different combinations of hybrids and weed. To establish the desired populations in each treatment and obtain uniformity of the seedlings, the seeds were previously sown in trays, and later transplanted to the pots.

At 50 days after the emergence of the species, the chlorophyll index $(\mathrm{CI})$, plant height $(\mathrm{PH})$, leaf area (LA) and DM were measured, both for maize and for the weed. To measure the CI, a portable chlorophyll meter model SPAD 502 - Plus was used, determining the measurements at five points of each plant, in the lower, middle and upper leaves of the canopy at random. The $\mathrm{PH}$ was measured with the aid of a millimeter ruler, measuring from the soil to the apex of the last fully expanded leaf of the plants. The determination of LA was performed with a portable leaf area meter model CI-203 BioScence, quantifying the variable in all plants in each treatment. After the quantification of LA, the shoot part of the plants was packed in paper bags and submitted to drying in a forced air circulation oven, at a temperature of $60 \pm 5{ }^{\circ} \mathrm{C}$, until a constant mass was obtained.

The data were analyzed using the method of graphic analysis of variation or relative productivity (COUSENS, 1991; BIANCHI; FLECK; LAMEGO, 2006; AGOSTINETTO et al., 2013). This procedure, also known as the conventional method for replacement experiments, consists of the construction of a diagram based on the relative (RP) and total (TRP) productivities or variations. When the RP result is a straight line, it means that the species' abilities are equivalent. If the RP results in a concave line, there was a loss in the growth of one or both species. Conversely, if RP results in a convex line, there is a benefit in the growth of one or both species. When TRP is equal to unit 1 (straight line), competition for the same resources occurs; if it exceeds 1 (convex line), competition is avoided. If the TRP is less than 1 (concave line), there is mutual damage to the growth (COUSENS, 1991).

Relative competitiveness (RC), relative clustering coefficient (K) and aggressiveness (A) of the species were also calculated. The RC represents the comparative growth of the maize hybrids $(\mathrm{X})$ to the wild poinsettia $(\mathrm{Y}) ; \mathrm{K}$ indicates the relative dominance of one species over the other; and A points out which species is more aggressive. Thus, the $\mathrm{RC}, \mathrm{K}$ and $\mathrm{A}$ indexes indicate which species is most competitive and their joint interpretation indicates with greater certainty the species' competitiveness. (COUSENS, 1991). For example, maize hybrids $\mathrm{X}$ are more competitive than wild poinsettia $\mathrm{Y}$ when $\mathrm{RC}>1, \mathrm{~K}_{\mathrm{x}}>\mathrm{K}_{\mathrm{y}}$ and $\mathrm{A}>0$; on the other hand, wild poinsettia $\mathrm{Y}$ is more competitive than maize hybrid $\mathrm{X}$ when $\mathrm{RC}<1, \mathrm{~K}_{\mathrm{x}}<\mathrm{K}_{\mathrm{y}}$ and A $<0$ (HOFFMAN; BUHLER, 2002; BIANCHI; FLECK; LAMEGO, 2006). To calculate the indices, the 50:50 proportions of the species involved in the experiment (maize versus wild poinsettia) were used, that is, the populations of 10:10 plants pot ${ }^{-1}$, using the equations: $\mathrm{RC}=\mathrm{RP}_{\mathrm{x}} / \mathrm{RP}_{\mathrm{y}} ; \mathrm{K}_{\mathrm{x}}=\mathrm{RP}_{\mathrm{x}} /\left(1-\mathrm{RP}_{\mathrm{x}}\right) ; \mathrm{K}_{\mathrm{y}}=$ $\mathrm{RP}_{\mathrm{y}} /\left(1-\mathrm{RP}_{\mathrm{y}}\right) ; \mathrm{A}=\mathrm{RP}_{\mathrm{x}}-\mathrm{RP}_{\mathrm{y}}$, according to Cousens and O'Neill (1993).

The procedure of statistical analysis of productivity or relative variation included the calculation of differences for the values of RP (DRP) obtained in the proportions 25,50 and $75 \%$ in relation to the values belonging to the hypothetical line in the respective proportions, that is, $0.25 ; 0.50$ and 0.75 for RP (BIANCHI; FLECK; LAMEGO, 2006; FLECK et al., 2008; AGOSTINETTO et al., 2013). Utilizou-se o teste $t$ para testar as diferenças relativas aos índices DPR, RTP, RC, K e A (HOFFMAN; BUHLER, 2002; BIANCHI; FLECK; LAMEGO, 2006). It was considered as a null hypothesis, to test the differences of DPR and A, that the averages were equal to zero $\left(\mathrm{H}_{0}=0\right)$; for TRP and $\mathrm{RC}$, that the averages were equal to one $\left(\mathrm{H}_{0}=1\right)$; and for $\mathrm{K}$, the averages of the differences between 
$\mathrm{K}_{\mathrm{x}}$ and $\mathrm{K}_{\mathrm{y}}$ were equal to zero $\left[\mathrm{H}_{\mathrm{o}}=\left(\mathrm{K}_{\mathrm{x}}-\mathrm{K}_{\mathrm{y}}\right)=0\right]$. The criterion for considering the RP and TRP curves different from the hypothetical lines was that, at least in two proportions, significant differences occurred by the "t" test. (BIANCHI; FLECK; LAMEGO, 2006; FLECK et al., 2008; AGOSTINETTO et al., 2013). Likewise, for the RC, $\mathrm{K}$ and A indices, differences in competitiveness were considered when, at least in two of them, there was a significant difference by the " $t$ " test.

The results obtained for $\mathrm{PH}, \mathrm{CI}, \mathrm{LA}$ and DM for both maize and competitor, expressed in average values per treatment, were subjected to analysis of variance by the $\mathrm{F}$ test, for each of the experiments (hybrids - Agroeste, Morgan, Nidera and Velox versus wild poinsettia) and when this was significant, the averages of treatments were compared using the Dunnett test, considering monocultures as control in these comparisons. In all statistical analyzes performed, $\mathrm{p} \leq 0.05$ was adopted.

\section{RESULTS AND DISCUSSION}

The variance analysis of the data demonstrated a significant effect between the proportions of plants of each maize hybrid and/or wild poinsettia for the variables, plant height $(\mathrm{PH})$, chlorophyll index (CI), leaf area (LA) and shoot dry mass (MS). Replacement experiments between maize hybrids versus wild poinsettia indicated competition between species, in which the productivity values obtained in different proportions between the two species, in general, deviated from the expected yield line (RP and RTP). In general, the association between the two species caused mutual damage (Figures 1, 2, 3 and 4; Tables 2, 3 and 4).

The graphical results indicate, in the combinations of the maize hybrids (Agroeste, Morgan, Nidera and Velox) with the competitor, that the expected RP values were very close to those observed for all studied variables (Figures 1, 2, 3 and 4, Table 2). It is also noteworthy that the maize hybrids showed similarities regarding competition with the wild poinsettia, with significant differences for the variables $\mathrm{PH}, \mathrm{CI}$, LA and DM, in the vast majority of the proportions of plants evaluated. Significant differences were observed in at least two proportions concerning the TRP for $\mathrm{PH}, \mathrm{CI}$, LA and DM of the hybrids Agroeste, Morgan, Nidera and Velox when competing with the wild poinsettia, with concave lines in most situations and average values below 1. It should be noted that only in three situations did TRP show values greater than 1 and a convex line, for the $\mathrm{PH}$ variable in the proportion of 25:75 involving the hybrid Agroeste and in the proportions 25:75 and 75:25 with Morgan (Figure 1 and Table 2).

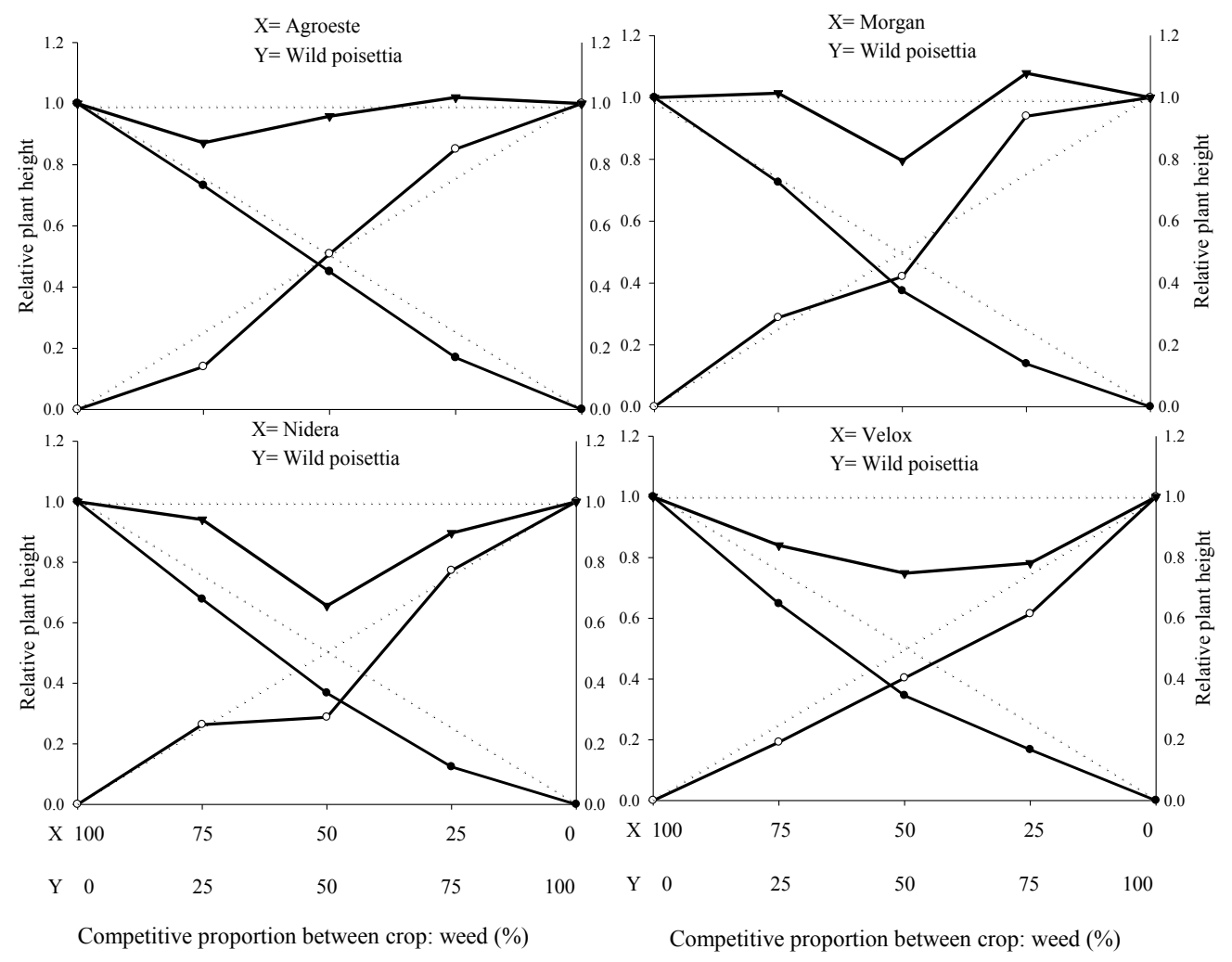

Figure 1. Relative productivity $(\mathrm{PR})$ for relative height of maize plants $(\bullet)$, wild poinsettia $(O)$, and total relative productivity (TRP) of the community $(\boldsymbol{\nabla})$ depending on the proportion of plants (maize: wild poinsettia). Dashed lines represent the expected values, in the absence of competition, and solid lines represent the values observed when species competed in different plant proportions. 
Table 2. Relative differences for the variables plant height, chlorophyll index, leaf area and dry mass of shoot parts of maize hybrids Agroeste (AS 1551 PRO 2), Morgan (MG 300 PW), Nidera (VT PRO Yeld Gard NS 92 PRO) and Syngenta (Velox TL) or wild poinsettia (Euphorbia heterophylla), 50 days after emergence.

\begin{tabular}{|c|c|c|c|}
\hline \multirow{3}{*}{ Variables } & \multicolumn{3}{|c|}{ Proportions of associated plants (maize: weed) } \\
\hline & $75: 25$ & $50: 50$ & $25: 75$ \\
\hline & \multicolumn{3}{|l|}{ Plant height } \\
\hline Agroeste (AS 1551 PRO 2) & $-0.02( \pm 0.02)$ & $-0.05( \pm 0.01)^{*}$ & $-0.08( \pm 0.001)^{*}$ \\
\hline Wild poinsettia & $-0.11( \pm 0.02)^{*}$ & $0.01( \pm 0.01)$ & $0.10( \pm 0.01)^{*}$ \\
\hline Total & $0.87( \pm 0.01) *$ & $0.96( \pm 0.01) *$ & $1.02( \pm 0.01)$ \\
\hline Morgan (MG 300 PW) & $-0.02( \pm 0.03)$ & $-0.13( \pm 0.01)^{*}$ & $-0.11( \pm 0.01)^{*}$ \\
\hline Wild poinsettia & $0.04( \pm 0.001)^{*}$ & $-0.08( \pm 0.02)^{*}$ & $0.19( \pm 0.01)^{*}$ \\
\hline Total & $1.01( \pm 0.03)$ & $0.80( \pm 0.02) *$ & $1.08( \pm 0.02) *$ \\
\hline Nidera (VT PRO Yeld Gard NS 92 PRO) & $-0.07( \pm 0.01)^{*}$ & $-0.13( \pm 0.02)^{*}$ & $-0.13( \pm 0.001)^{*}$ \\
\hline Wild poinsettia & $0.01( \pm 0,01)$ & $-0.21( \pm 0.01)^{*}$ & $0.02( \pm 0.01)$ \\
\hline Total & $0.94( \pm 0.001)^{*}$ & $0.66( \pm 0.03) *$ & $0.90( \pm 0.01)^{*}$ \\
\hline Syngenta (Velox TL) & $-0.10( \pm 0.01)^{*}$ & $-0.15( \pm 0.01)^{*}$ & $-0.08( \pm 0.01)^{*}$ \\
\hline Wild poinsettia & $-0.06( \pm 0.001)^{*}$ & $-0.10( \pm 0.01)^{*}$ & $-0.14( \pm 0.03)^{*}$ \\
\hline Total & $0.84( \pm 0.01)^{*}$ & $0.75( \pm 0.01) *$ & $0.78( \pm 0.04) *$ \\
\hline \multicolumn{4}{|c|}{ Chlorophyll index } \\
\hline Agroeste (AS 1551 PRO 2) & $0.08( \pm 0.08)$ & $-0.04( \pm 0.03)$ & $-0.04( \pm 0.01)^{*}$ \\
\hline Wild poinsettia & $-0.09( \pm 0.01)^{*}$ & $0.03( \pm 0.03)$ & $-0.10( \pm 0.09)$ \\
\hline Total & $0.99( \pm 0.07)$ & $0.98( \pm 0.01)$ & $0.86( \pm 0.09)$ \\
\hline Morgan (MG 300 PW) & $-0.04( \pm 0.01)$ & $-0.12( \pm 0.001)^{*}$ & $-0.10( \pm 0.01)^{*}$ \\
\hline Wild poinsettia & $-0.07( \pm 0.02)$ & $-0.11( \pm 0.001)^{*}$ & $-0.04( \pm 0.02)$ \\
\hline Total & $0.89( \pm 0.01)^{*}$ & $0.78( \pm 0.001) *$ & $0.86( \pm 0.02) *$ \\
\hline Nidera (VT PRO Yeld Gard NS 92 PRO) & $-0.05( \pm 0.001)^{*}$ & $-0.12( \pm 0.01)^{*}$ & $-0.13( \pm 0.001)^{*}$ \\
\hline Wild poinsettia & $-0.06( \pm 0.01)^{*}$ & $-0.20( \pm 0.001)^{*}$ & $-0.004( \pm 0.01)$ \\
\hline Total & $0.89( \pm 0.01)^{*}$ & $0.68( \pm 0.01)^{*}$ & $0.86( \pm 0.01)^{*}$ \\
\hline Syngenta (Velox TL) & $0.04( \pm 0.05)$ & $-0.09( \pm 0.02)^{*}$ & $-0.06( \pm 0.001)^{*}$ \\
\hline Wild poinsettia & $-0.13( \pm 0.02)^{*}$ & $-0.25( \pm 0.01)^{*}$ & $-0.28( \pm 0.01)^{*}$ \\
\hline Total & $0.91( \pm 0.03)$ & $0.66( \pm 0.02) *$ & $0.66( \pm 0.01) *$ \\
\hline \multicolumn{4}{|c|}{ Leaf area } \\
\hline Agroeste (AS 1551 PRO 2) & $-0.25( \pm 0.03)^{*}$ & $-0.34( \pm 0.01)^{*}$ & $-0.19( \pm 0.001)^{*}$ \\
\hline Wild poinsettia & $-0.24( \pm 0.001)^{*}$ & $-0.47( \pm 0.001)^{*}$ & $-0.59( \pm 0.01)^{*}$ \\
\hline Total & $0.51( \pm 0.03) *$ & $0.19( \pm 0.01) *$ & $0.21( \pm 0.01) *$ \\
\hline Morgan (MG 300 PW) & $-0.26( \pm 0.01)^{*}$ & $-0.21( \pm 0.02)^{*}$ & $-0.20( \pm 0.001)^{*}$ \\
\hline Wild poinsettia & $-0.23( \pm 0.001)^{*}$ & $-0.16( \pm 0.02)^{*}$ & $-0.10( \pm 0.09)$ \\
\hline Total & $0.52( \pm 0.01)^{*}$ & $0.62( \pm 0.04)^{*}$ & $0.70( \pm 0.09)$ \\
\hline Nidera (VT PRO Yeld Gard NS 92 PRO) & $-0.13( \pm 0.04)$ & $-0.32( \pm 0.01)^{*}$ & $-0.20( \pm 0.001)^{*}$ \\
\hline Wild poinsettia & $-0.22( \pm 0.001)^{*}$ & $-0.38( \pm 0.01)^{*}$ & $-0.39( \pm 0.01)^{*}$ \\
\hline Total & $0.65( \pm 0.04) *$ & $0.30( \pm 0.01) *$ & $0.41( \pm 0.01) *$ \\
\hline Syngenta (Velox TL) & $-0.24( \pm 0.01)^{*}$ & $-0.37( \pm 0.001)^{*}$ & $-0.19( \pm 0.001)^{*}$ \\
\hline Wild poinsettia & $-0.22( \pm 0.001)^{*}$ & $-0.47( \pm 0.001)^{*}$ & $-0.40( \pm 0.01)^{*}$ \\
\hline Total & $0.55( \pm 0.01)^{*}$ & $0.17( \pm 0.01 *)$ & $0.41( \pm 0.01)^{*}$ \\
\hline \multicolumn{4}{|c|}{ Shoot dry mass } \\
\hline Agroeste (AS 1551 PRO 2) & $-0.05( \pm 0.07)$ & $-0.32( \pm 0.02)^{*}$ & $-0.16( \pm 0.01)^{*}$ \\
\hline Wild poinsettia & $-0.23( \pm 0.01)^{*}$ & $-0.27( \pm 0.01)^{*}$ & $-0.31( \pm 0.08)$ \\
\hline Total & $0.72( \pm 0.08)$ & $0.41( \pm 0.03)^{*}$ & $0.52( \pm 0.09)^{*}$ \\
\hline Morgan (MG 300 PW) & $-0.35( \pm 0.01)^{*}$ & $-0.30( \pm 0.01)^{*}$ & $-0.17( \pm 0.01)^{*}$ \\
\hline Wild poinsettia & $-0.22( \pm 0.001)^{*}$ & $-0.38( \pm 0.01)^{*}$ & $-0.35( \pm 0.02)^{*}$ \\
\hline Total & $0.43( \pm 0.01)^{*}$ & $0.32( \pm 0.01) *$ & $0.47( \pm 0.03) *$ \\
\hline Nidera (VT PRO Yeld Gard NS 92 PRO) & $-0.50( \pm 0.01)^{*}$ & $-0.29( \pm 0.01)^{*}$ & $-0.20( \pm 0.001)^{*}$ \\
\hline Wild poinsettia & $-0.22( \pm 0.001)^{*}$ & $-0.29( \pm 0.01)^{*}$ & $-0.28( \pm 0.03)^{*}$ \\
\hline Total & $0.29( \pm 0.01)^{*}$ & $0.41( \pm 0.01)^{*}$ & $0.51( \pm 0.03) *$ \\
\hline Syngenta (Velox TL) & $-0.20( \pm 0.03)^{*}$ & $-0.19( \pm 0.001)^{*}$ & $-0.17( \pm 0.01)^{*}$ \\
\hline Wild poinsettia & $-0.21( \pm 0.01)^{*}$ & $-0.22( \pm 0.01)^{*}$ & $-0.21( \pm 0.01)^{*}$ \\
\hline Total & $0.58( \pm 0.02) *$ & $0.59( \pm 0.01) *$ & $0.62( \pm 0.01) *$ \\
\hline
\end{tabular}

*Significant difference by the " $t$ " test $(\mathrm{p} \leq 0.05)$. Values in parentheses represent the standard error of the average.

In all situations, there were significant differences for RP, except for the PH for the weed with the Nidera hybrid and for the CI for the
Agroeste hybrid and also the wild poinsettia. Considering that to be significant, at least two proportions of plants must present significant 
differences by the " $\mathrm{t}$ " test (BIANCHI; FLECK; LAMEGO, 2006).

The results of the TRP of concave lines and values less than 1 , allow us to infer that there was a competition between maize and wild poinsettia for the same environmental resources. When TRP $<1$ there is a mutual antagonism between the species that are competing for the same resources of the environment and in the same proportion, without changing the final productivity (COUSENS, 1991; RUBIN et al., 2014). Similar results to the present study were found when maize hybrids were in the presence of sudangrass - Sorghum sudanense (WANDSCHEER et al., 2014), plantain alexandergrass - Urochloa plantaginea (FRANDOLOSO et al., 2019), crabgrass - Digitaria ciliaris and morningglory - Ipomoea indivisa (GALON et al., 2021).

It was observed for the variables PH, CI, LA and $\mathrm{DM}$ in all combinations of plants involving the maize hybrids and wild poinsettia that the deviations of the RP lines in relation to the expected lines, in general presenting concave lines, except in four situations: when Agroeste and Morgan competed with the weed in the proportion of 25:75 $\mathrm{PH}$ that presented a convex line for the weed (Figure 1; Table 2). And for the variable $\mathrm{CI}$ in the proportion of 75:25 involving the hybrid Agroeste and Velox versus wild poinsettia, which also presented a convex line. This shows that the crop and the weed compete for the same resources of the environment in which they are inserted, with mutual damage to the growth of the species. When studying the effect of competition on corn with sudangrass (WANDSCHEER et al., 2014), with alexandergrass (FRANDOLOSO et al., 2019), with maize and/or morningglory (GALON et al., 2021) and soybeaninfesting weeds (FORTE et al., 2017) also found the occurrence of concave lines for the crop and competitor for the evaluated variables, which corroborates with what was found in the present study.

When evaluating Figures 1, 2, 3 and 4, it was found that, in all proportions, there was a decrease in the variables, especially LA and DM according to the increase in the wild poinsettia population, that is, the observed RPs were much lower than expected, with concave lines. For PH (Figure 1 and Table 3 ) in the same crop population with the weed (50:50), there was a significant difference, with reductions greater than 10, 25, 26 and $25 \%$ for the Agroeste, Morgan, Nidera and Velox hybrids, respectively, when compared to the control free of the weed. In the case of the CI (Figure 2 and Table 3), there was a significant difference for the Morgan, Nideira and Velox hybrids when comparing the $50: 50$ proportion with the control free of the weed, with reductions of 23,25 and $18 \%$, respectively.

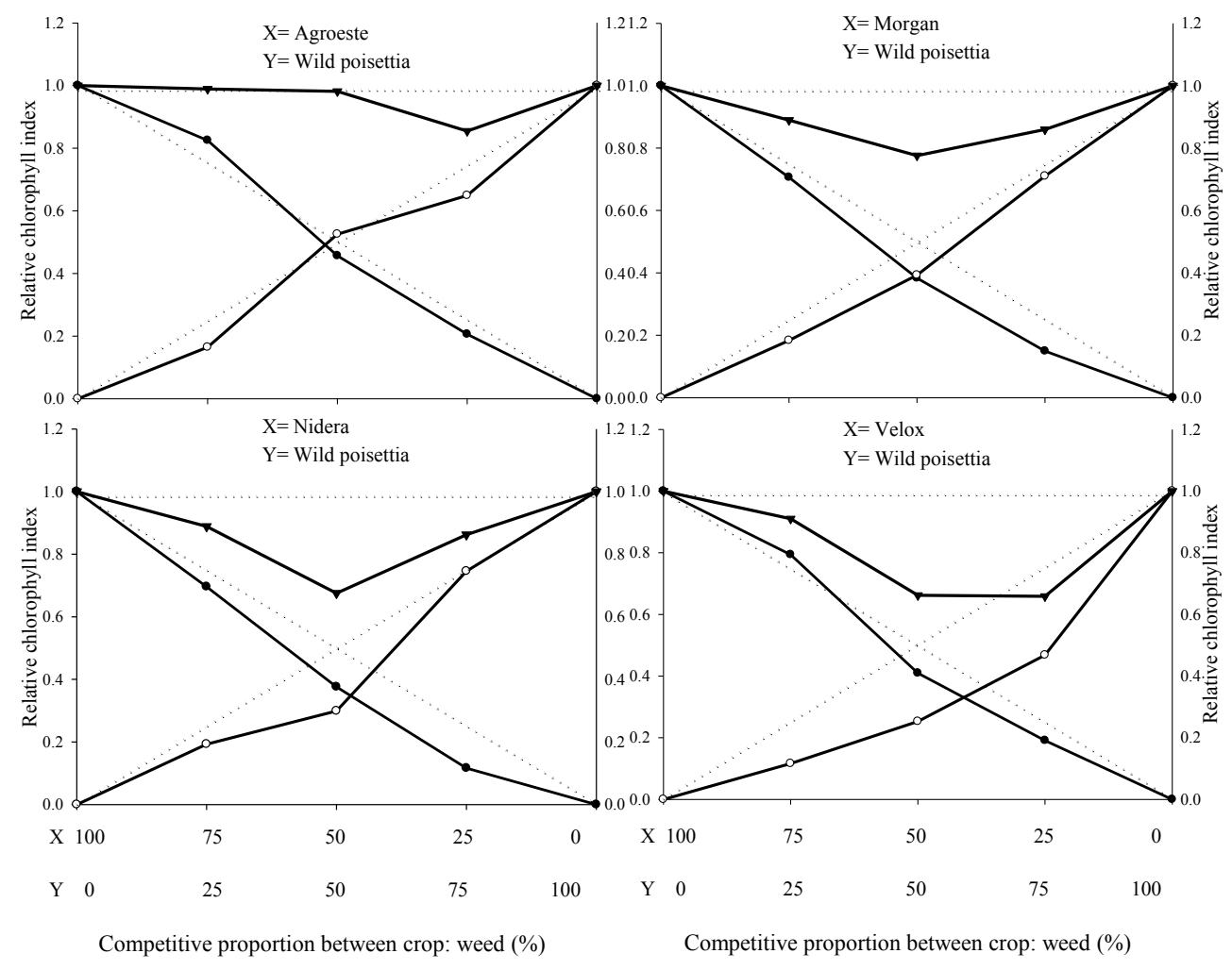

Figure 2. Relative productivity $(\mathrm{RP})$ for chlorophyll index (SPAD) relative of the maize plants $(\bullet)$, wild poinsettia $(O)$, and total relative productivity (TRP) of the community $(\boldsymbol{\nabla})$ depending on the proportion of plants (maize: wild poinsettia). Dashed lines represent the expected values, in the absence of competition, and solid lines represent the values observed when species competed in different plant proportions. 
When observing the variable LA (Figure 3 and Table 3) in the same crop versus competitor population (50:50) there was a significant difference, with reductions greater than $68,42,65$ and $73 \%$ for the Agroeste, Morgan, Nidera and Velox hybrids, respectively, when compared to the control free of wild poinsettia.

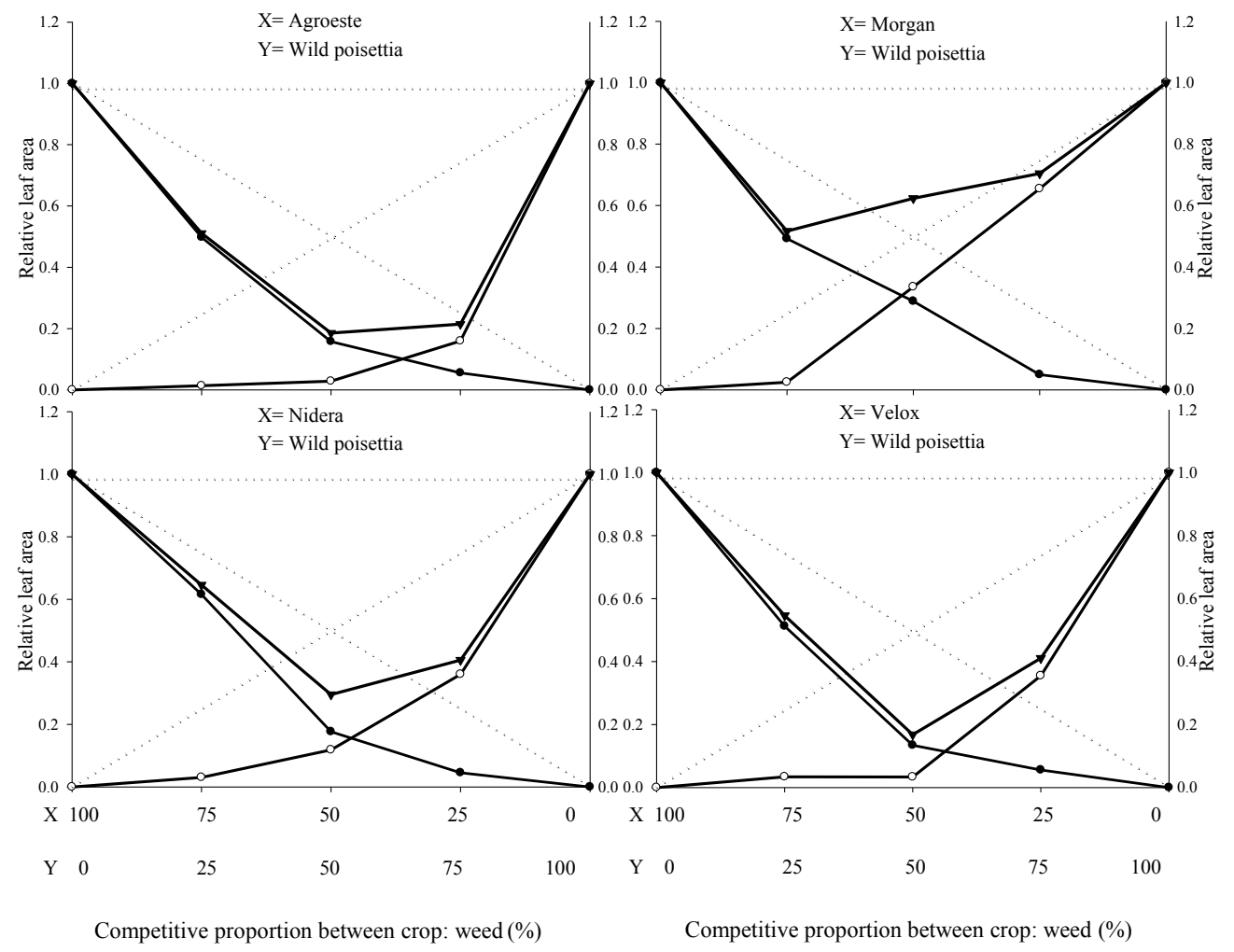

Figure 3. Relative productivity (RP) for relative leaf area of maize plants $(\bullet)$ or wild poinsettia $(\bigcirc)$, and total relative productivity (TRP) of the community ( $\mathbf{\nabla})$ depending on the proportion of plants (maize: wild poinsettia). Dashed lines represent the expected values, in the absence of competition, and solid lines the values.

Table 3. Differences between plants associated or not with maize hybrids Agroeste (AS 1551 PRO 2), Morgan (MG 300 PW), Nidera (VT PRO Yeld Gard NS 92 PRO) and Syngenta (Velox TL) and wild poinsettia (Euphorbia heterophylla) for the variables plant height, chlorophyll index, leaf area and shoot dry mass, at 50 days after the emergence.

\begin{tabular}{|c|c|c|c|c|c|c|c|c|}
\hline \multirow{3}{*}{$\begin{array}{l}\text { Proportion } \\
\text { Maize: weed } \\
\text { Weed: maize }\end{array}$} & \multicolumn{2}{|c|}{ Plant height } & \multicolumn{2}{|c|}{ Chlorophyll index } & \multicolumn{2}{|c|}{ Leaf area } & \multicolumn{2}{|c|}{ Dry mass } \\
\hline & \multicolumn{8}{|c|}{ Agroeste $v s$ wild poinsettia } \\
\hline & Maize & Weed & Maize & Weed & Maize & Weed & Maize & Weed \\
\hline $100: 0(\mathrm{~T})$ & 44.55 & 15.32 & 25.96 & 34.96 & 2583.51 & 503.58 & 23.97 & 4.75 \\
\hline $75: 25$ & 43.49 & 17.38 & 28.56 & 30.24 & $1713.91 *$ & $107.00 *$ & 22.33 & $2.78^{*}$ \\
\hline $50: 50$ & $40.13^{*}$ & 15.58 & 23.70 & 36.76 & $814.38^{*}$ & $28.24 *$ & $8.65^{*}$ & $2.19 *$ \\
\hline $25: 75$ & $30.17^{*}$ & $8.56^{*}$ & 21.40 & $22.98^{*}$ & $571.41 *$ & $27.38^{*}$ & $7.58^{*}$ & $0.38 *$ \\
\hline$C V(\%)$ & 3.51 & 8.30 & 10.70 & 14.01 & 16.33 & 20.66 & 16.21 & 24.40 \\
\hline \multirow{2}{*}{ Proportion } & \multicolumn{8}{|c|}{ Morgan $v s$ wild poinsettia } \\
\hline & Maize & Weed & Maize & Weed & Maize & Weed & Maize & Weed \\
\hline 100:0 (T) & 45.33 & 13.29 & 29.11 & 34.77 & 1652.40 & 159.17 & 19.50 & 7.49 \\
\hline $75: 25$ & 43.87 & $16.66^{*}$ & 27.41 & 32.93 & $1083.95^{*}$ & 138.10 & $10.38^{*}$ & $3.95 *$ \\
\hline $50: 50$ & $33.98^{*}$ & $11.19^{*}$ & $22.31 *$ & $27.31 *$ & $952.74 *$ & 106.69 & $7.83^{*}$ & $1.82 *$ \\
\hline $25: 75$ & $25.21^{*}$ & $15.32 *$ & $17.38^{*}$ & $25.52^{*}$ & $327.93 *$ & $15.81^{*}$ & $5.96^{*}$ & $1.03 *$ \\
\hline$C V(\%)$ & 6.84 & 4.16 & 4.01 & 7.95 & 18.54 & 24.57 & 8.47 & 12.48 \\
\hline
\end{tabular}

*Average differs from control $(\mathrm{T})$ by Dunnett's test $(\mathrm{p} \leq 0.05)$.

Rev. Caatinga, Mossoró, v. 34, n. 2, p. 298 - 309, abr. - jun., 2021 
Table 3. Continuation

\begin{tabular}{|c|c|c|c|c|c|c|c|c|}
\hline \multirow{3}{*}{$\begin{array}{c}\text { Proportion } \\
\text { Maize: weed } \\
\text { Weed: maize } \\
\text { Proportion }\end{array}$} & \multicolumn{2}{|c|}{ Plant height } & \multicolumn{2}{|c|}{ Chlorophyll index } & \multicolumn{2}{|c|}{ Leaf area } & \multicolumn{2}{|c|}{ Dry mass } \\
\hline & \multicolumn{8}{|c|}{ Nidera $v s$ wild poinsettia } \\
\hline & Maize & Weed & Maize & Weed & Maize & Weed & Maize & Weed \\
\hline 100:0 (T) & 51.14 & 16.59 & 33.52 & 40.56 & 2752.93 & 502.92 & 35.87 & 4.03 \\
\hline $75: 25$ & 46.22 & 17.09 & $31.11 *$ & 40.33 & $2259.40^{*}$ & $241.58^{*}$ & $12.09 *$ & $2.52 *$ \\
\hline $50: 50$ & $37.62 *$ & $9.56^{*}$ & $25.21 *$ & $24.26^{*}$ & $971.58 *$ & $119.36^{*}$ & $14.82 *$ & $1.67^{*}$ \\
\hline $25: 75$ & $25.33^{*}$ & 17.47 & $15.59^{*}$ & $31.25^{*}$ & $500.66^{*}$ & $61.21^{*}$ & $6.49^{*}$ & $0.55^{*}$ \\
\hline$C V(\%)$ & 5.75 & 5.76 & 2.64 & 2,79 & 7.43 & 10.49 & 20.73 & 15.43 \\
\hline \multirow{2}{*}{ Proportion } & \multicolumn{8}{|c|}{ Velox $v s$ wild poinsettia } \\
\hline & Maize & Weed & Maize & Weed & Maize & Weed & Maize & Weed \\
\hline $100: 0(\mathrm{~T})$ & 43.23 & 17.16 & 22.67 & 45.26 & 2593.70 & 598.73 & 19.44 & 2.82 \\
\hline $75: 25$ & $40.80^{*}$ & $14.06^{*}$ & 24.00 & $28.24 *$ & $1771.73 *$ & $283.23 *$ & $14.16^{*}$ & $2.02 *$ \\
\hline $50: 50$ & $32.63 *$ & $13.84 *$ & $18.56^{*}$ & $22.87^{*}$ & $696.94 *$ & $38.23 *$ & $12.09 *$ & $1.59 *$ \\
\hline $25: 75$ & $30.73^{*}$ & $13.18^{*}$ & $17.31^{*}$ & $21.03^{*}$ & $580.19 *$ & $80.87^{*}$ & $6.49^{*}$ & $0.43 *$ \\
\hline$C V(\%)$ & 4.56 & 6.23 & 8.22 & 14.40 & 4.70 & 3.34 & 7.96 & 7.32 \\
\hline
\end{tabular}

*Average differs from control $(\mathrm{T})$ by Dunnett's test $(\mathrm{p} \leq 0.05)$.

Using the same comparison for the DM variable (Figure 4 and Table 3), a decrease of 64, 60, 59 and $38 \%$ was found, respectively for the Agroeste, Morgan, Nidera and Velox hybrids in association with the weed. According to Bianchi,
Fleck and Lamego (2006), plant species when living in a community can respond to competition by reducing growth due to the effect of interference between them, which corroborates what was observed in the present study.

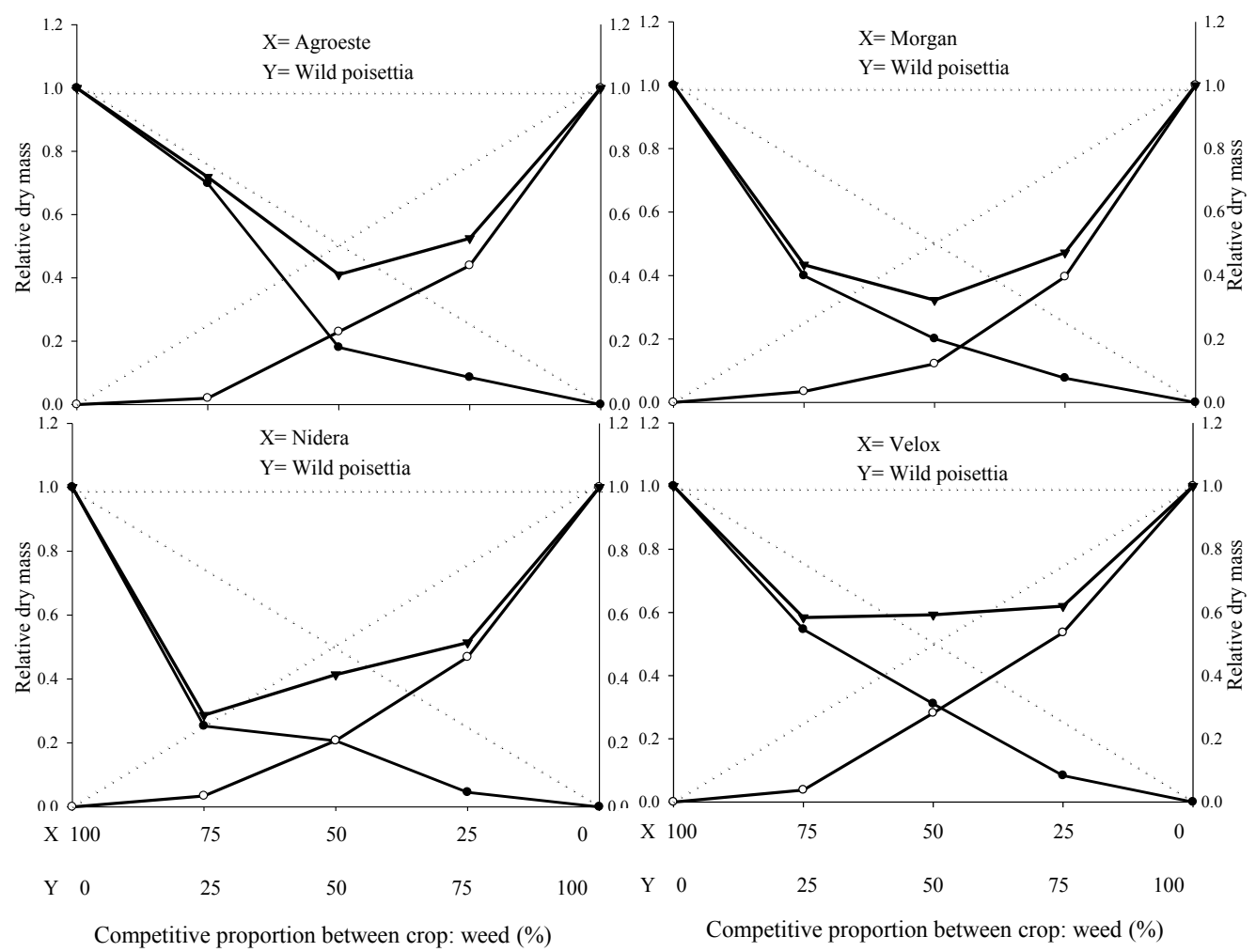

Figure 4. Relative productivity $(\mathrm{RP})$ for relative dry mass of maize plants $(\bullet)$, wild poinsettia $(\bigcirc)$, and total relative productivity (TRP) of the community $(\boldsymbol{\nabla})$ depending on the proportion of plants (maize: wild poinsettia). Dashed lines represent the expected values, in the absence of competition, and solid lines represent the values observed when species competed in different plant proportions. 
In general, maize hybrids showed greater relative growth than wild poinsettia in all the proportions of plants evaluated for the variables tested, with higher RP for the crop and lower for the weed, however, they presented a little contribution to the TRP (Figures 1, 2, 3 and 4; Table 2). It can be reported that the probable cause of maize has greater relative growth than that of the wild poinsettia is related to the height of plants, making it more efficient in the search for solar radiation and imposing shading on the weed (MEROTTO JR; FISCHER; VIDAL, 2009). When one species is more competitive than another, it will indicate that it will have a greater capacity to assimilate the resources available in the environment and thus increase the potential for growth and development, which generates increased damage to the competitor, since lesser amounts of resources will be available (AGOSTINETTO et al., 2013). Thus, the competition for quantity and quality of light is the result of the proximity of plants, which compromises the increase of LA and DM, as there is interference in the formation and growth of leaves (WU et al., 2012). It should be noted that, in replacement experiments, there is little evidence of qualitative changes due to population growth, that is, the dominance of one species over the other rarely changes with the change of the population (COUSENS; O'NEILL, 1993).

The results demonstrate, in general, the higher TRP values of all combinations, the higher the proportions of corn plants in the simulations and the lower that of the weed when competing with each other - a significant situation for both variables studied (Table 2). This behavior shows that the species are competitive and that one does not contribute more than expected to the total productivity of the other (COUSENS, 1991). Similar results to the present study were found when maize hybrids competed with plantain alexandergrass (FRANDOLOSO et al., 2019) with crabgrass and morningglory (GALON et al., 2021), that is, the TRPs presented the highest values when the crop appeared in a greater proportion than the weed in the associations.

It was observed that all variables (PH, CI, LA and DM) of the different evaluated maize hybrids (Agroeste, Morgan, Nidera and Velox) were reduced when they competed with the weed in all the analyzed combinations, regardless of the proportion of plants in the association (Table 3 ). However, the higher the proportion of the competitor in the association with the hybrids, the greater the damage. In the wild poinsettia, the same reduction trend was observed. Research has reported that damage to crop and weed growth can occur when they compete in a particular community (FLECK et al., 2008; AGOSTINETTO et al., 2013; WANDSCHEER et al., 2014; FRANDOLOSO et al., 2019; GALON et al., 2021).
It was observed, in general, for the variables LA and DM that the highest averages per plant of the crop or even of the wild poinsettia were obtained when they competed in smaller populations in the association in all combinations (Table 3). Thus, it appears that interspecific competition is more harmful to both species involved than intraspecific competition. Frandoloso et al. (2019) and Galon et al. (2021) also observed that the effect of interspecific competition was more harmful than intraspecific when working with different maize hybrids in the presence of plantain alexandergrass, crabgrass and morningglory. Zanine and Santos (2004) describe that the reduction in the growth of species, involved in intra or interspecific combinations, results from the spatial competition between groups of plants that occupy the same space. Other studies involving different species of plants in competition also showed similar effects to those found in the present study, rice in competition with red rice (FLECK et al., 2008), rice and soybean $x$ crabgrass (AGOSTINETTO et al., 2013), wheat $x$ radish (COSTA; RIZZARDI, 2015), wheat $x$ ryegrass (MARIANI et al., 2016), soybean x weeds (FORTE et al., 2017) and maize $x$ plantain alexandergrass (FRANDOLOSO et al., 2019) or maize x crabgrass or morningglory (GALON et al., 2021).

Bianchi, Fleck and Lamego (2006) describe that competition affects production quantitatively and qualitatively, as it changes the efficiency of the use of environmental resources, such as water, light, $\mathrm{CO}_{2}$ and nutrients, establishing itself between the culture and plants of other species existing in the place. This competition also occurs between individuals of the same species or between biotypes predominant in the area, as verified by Schaedler et al. (2013), for biotypes of resistant and susceptible Fimbristylis miliacea to ALS enzyme inhibitors where there were differences in their adaptive values at the beginning of flowering. It is also noteworthy that in a plant community there is a benefit in the competition for resources for those who establish themselves first, due to the intrinsic characteristics of each cultivar or hybrid in terms of competitive ability (root system, height, leaf area index, dry mass production, growth speed, number of tillers, among others), due to the better use or need of resources by a given species within an ecological niche.

The maize hybrid X (Agroeste, Morgan, Nidera and Velox) is more competitive than the wild poinsettia $\mathrm{Y}$, when compared by the competitiveness indexes developed by Hoffman and Buhler (2000), $\mathrm{RC}>1, \mathrm{~K}_{\mathrm{x}}>\mathrm{K}_{\mathrm{y}}$ and $\mathrm{A}>0$. Thus, it was adopted as a criterion to prove competitive superiority, the occurrence of a significant difference in at least two of these indexes (BIANCHI; FLECK; LAMEGO, 2006). The results demonstrate different responses between the hybrids and variables analyzed, and this is attributed to the genetic differences between the 
maize materials selected for the study (Table 1). For PH (Table 4), only Nidera showed greater growth when in competition, as indicated by the RC (greater than 1), K of the crop greater than the weed and A (positive). Morgan had no significant effect on the presence of the weed and in the other hybrids, the wild poinsettia was more competitive than the crop. Still, following this same observation criterion for the variable $\mathrm{CI}$, greater competitiveness was observed for the hybrids Nidera and Velox, since Agroeste and Morgan in competition with the wild poinsettia have not shown a significant effect in at least two indexes. It was observed for LA that only
Morgan does not show a significant effect for the evaluated indexes, all other hybrids, the culture was more competitive than the wild poinsettia. For DM, Nidera and Velox in competition with the weed did not show significance in at least two of the indexes, Agroeste was less competitive than weed and Morgan demonstrated $\mathrm{RC}>1, \mathrm{Kx}>\mathrm{Ky}$ and $\mathrm{A}$ positive. However, it is clear that only the Nidera hybrid demonstrated $\mathrm{RC}>1, \mathrm{Kx}>\mathrm{Ky}$ and A positive for three of the four variables studied, that is, $\mathrm{PH}, \mathrm{CI}$ and LA and for DM there was no significance in the effect of competition taking into account the relative competitiveness indexes.

Table 4. Competitiveness indices between maize hybrids (Agroeste (AS 1551 PRO 2), Morgan (MG 300 PW), Nidera (VT PRO Yeld Gard NS 92 PRO) and Syngenta (Velox TL) and wild poinsettia (Euphorbia heterophylla), expressed by relative competitiveness (CR), coefficients of relative groupings (K) and aggressiveness (A), obtained in experiments conducted in replacement series, at $50 \mathrm{DAE}$.

\begin{tabular}{|c|c|c|c|c|}
\hline \multirow{2}{*}{ Variable } & $\mathrm{RC}$ & $\mathrm{K}_{\mathrm{x} \text { maize }}$ & $\mathrm{K}_{\mathrm{y} \text { weed }}$ & A \\
\hline & \multicolumn{4}{|c|}{ Plant height } \\
\hline Agroeste $\mathrm{x}$ weed & $0.89( \pm 0.02)^{*}$ & $0.82( \pm 0.02)^{*}$ & $1.04( \pm 0.03)^{*}$ & $-0.06( \pm 0.01)^{*}$ \\
\hline Morgan x weed & $0.89( \pm 0.04)$ & $0.60( \pm 0.02)$ & $0.73( \pm 0.06)$ & $-0.05( \pm 0.02)$ \\
\hline Nidera $\mathrm{x}$ weed & $1.28( \pm 0.07)^{*}$ & $0.59( \pm 0.06)^{*}$ & $0.40( \pm 0.01)$ & $0.08( \pm 0.02)^{*}$ \\
\hline Velox x weed & $0.86( \pm 0.05)$ & $0.53( \pm 0.03)^{*}$ & $0.68( \pm 0.04)^{*}$ & $-0.06( \pm 0.02)$ \\
\hline \multicolumn{5}{|c|}{ Chlorophyll index } \\
\hline Agroeste $\mathrm{x}$ weed & $0.88( \pm 0.10)$ & $0.85( \pm 0.10)$ & $1.12( \pm 0.12)$ & $-0.07( \pm 0.05)$ \\
\hline Morgan x weed & $0.98( \pm 0.01)$ & $0.62( \pm 0.01)$ & $0.65( \pm 0.009)$ & $-0.01( \pm 0,01)$ \\
\hline Nidera $\mathrm{x}$ weed & $1.26( \pm 0.04)^{*}$ & $0.60( \pm 0.03)^{*}$ & $0.43( \pm 0.006)^{*}$ & $0.08( \pm 0.01)^{*}$ \\
\hline Velox $\mathrm{x}$ weed & $1.63( \pm 0.14)^{*}$ & $0.70( \pm 0.05)^{*}$ & $0.34( \pm 0.02)^{*}$ & $0.16( \pm 0.03)^{*}$ \\
\hline \multicolumn{5}{|c|}{ Leaf area } \\
\hline Agroeste $\mathrm{x}$ weed & $5.62( \pm 0.44)^{*}$ & $0.19( \pm 0.02)^{*}$ & $0.03( \pm 0.0001)^{*}$ & $0.13( \pm 0.01)^{*}$ \\
\hline Morgan x weed & $0.86( \pm 0.07)$ & $0.41( \pm 0.05)$ & $0.51( \pm 0.04)^{*}$ & $-0.05( \pm 0.02)$ \\
\hline Nidera $\mathrm{x}$ weed & $1.51( \pm 0.17)$ & $0.21( \pm 0.01)^{*}$ & $0.13( \pm 0.01)^{*}$ & $0.06( \pm 0.01)$ \\
\hline Velox x weed & $4.00( \pm 0.07)^{*}$ & $0.16( \pm 0.006)^{*}$ & $0.03( \pm 0.001)^{*}$ & $0.10( \pm 0.001)^{*}$ \\
\hline \multicolumn{5}{|c|}{ Shoot dry mass } \\
\hline Agroeste $\mathrm{x}$ weed & $0.71( \pm 0.04)^{*}$ & $0.22( \pm 0.03)$ & $0.30( \pm 0.02)$ & $-0.005( \pm 0.01)^{*}$ \\
\hline Morgan x weed & $1.67( \pm 0.19)$ & $0.25( \pm 0.02)^{*}$ & $0.14( \pm 0.08)^{*}$ & $0.08( \pm 0.02)^{*}$ \\
\hline Nidera $\mathrm{x}$ weed & $1.00( \pm 0.04)$ & $0.26( \pm 0.01)$ & $0.26( \pm 0.03)$ & $-0.0008( \pm 0.01)$ \\
\hline Velox x weed & $1.11( \pm 0.04)$ & $0.45( \pm 0.03)^{*}$ & $0.39( \pm 0.02)$ & $0.03( \pm 0.01)$ \\
\hline
\end{tabular}

*Significant difference by the $t$ test $(p<0.05)$. Values in parentheses represent the standard error of the average. $K_{x}$ and $K_{y}$ are the relative grouping coefficients of the maize hybrids and weed competitor, respectively.

Corroborating with the results of the relative competitiveness indexes found in the present study, it is highlighted that maize was more competitive than plantain alexandergrass (FRANDOLOSO et al., 2019), the morningglory (GALON et al., 2021) or sudangrass (WANDSCHEER et al., 2014). Using the three indexes to define competitiveness, it was observed that the cultivated sorghum was more competitive than Sorghum halepense (HOFFMAN; BUHLER, 2002), that soybean cultivars were more competitive than weeds (FORTE et al., 2017), that rice- red showed greater aggressiveness than rice (FLECK et al., 2008), and that soybeans and rice were more competitive than crabgrass (AGOSTINETTO et al., 2013).

Interpreting the graphical analyzes of relative 
variables and their significance to the equivalent values (Figures 1, 2, 3 and 4; Table 2), the morphological variables (Table 3) and the competitiveness indexes (Table 4). In general, it was found that there is a negative interaction effect between species, with the maize hybrids Agroeste, Morgan, Nidera and Velox, as well as the wild poinsettia being affected. Corn hybrids, in general, demonstrated losses in the variables evaluated whenever the proportion of weed was increased in relation to maize. Also, concerning competitiveness, the behavior of the hybrids was different according to the observed variable, and it can be inferred that Nideira and Velox are slightly more competitive than Agroeste and Morgan when living with the wild poinsettia. In addition to the loss of control efficiency by herbicides to which the weed has resistance (HEAP, 2020), the coexistence of this weed with maize can cause serious losses due to its high competitiveness, as shown in the present study. This work confirms the results found by Vazin (2012), Wandscheer et al. (2014), Frandoloso et al. (2019); Galon et al. (2019) and Galon et al. (2021) when they denote that competition occurred between corn grown in the presence of slender amaranth, sudangrass, plantain alexandergrass, crabgrass and morningglory, respectively.

Research has reported that species belonging to botanical families, with similar or different characteristics, have similarities in the demand for resources in the environment; cultivated sorghum $\mathrm{x}$ Sorghum halepense (HOFFMAN; BUHLER, 2002), rice $\mathrm{x}$ redrice (FLECK et al., 2008), maize $\mathrm{x}$ crabgrass and morningglory (GALON et al., 2021), maize $x$ plantain alexandergrass (FRANDOLOSO et al., 2019; GALON et al., 2019), maize x sudangrass (WANDSCHEER; RIZZARDI; REICHERT, 2013), rice and soybean $\mathrm{x}$ crabgrass (AGOSTINETTO et al., 2013) and soybean x radish (BIANCHI; FLECK; LAMEGO, 2006). The knowledge of dynamics and competitiveness between plants, especially maize and wild poinsettia, becomes important for the decision to control the weed in a certain population that will not cause negative interference on the crop.

\section{CONCLUSIONS}

There is a competition between the maize hybrids (Agroeste, Morgan, Nidera and Velox) with the wild poinsettia, being negatively affected, regardless of the proportion of plants, causing reductions in plant height, chlorophyll index, leaf area and shoot dry mass of the plant species. Maize and wild poinsettia compete for the same resources in the environment. When comparing the species to each other, in general, it was observed that only the hybrids Nideira and Velox were more competitive than the weed. Interspecific competition causes greater damage to maize and wild poinsettia than intraspecific competition.

\section{ACKNOWLEDGMENT}

To CNPq, FAPERGS, UFFS and FINEP for the financial aid for research and scholarships.

\section{REFERENCES}

AGOSTINETTO, D. et al. Relative competitive ability of crabgrass in coexistence with flooded rice and soybean. Pesquisa Agropecuária Brasileira, 48: 1315-1322, 2013.

AGOSTINETTO, D. et al. Morphophysiogenetic characterization of wild poinsettia biotypes with low resistance to glyphosate. Pesquisa Agropecuária Brasileira, 52: 987-996, 2017.

BIANCHI, M. A.; FLECK, N. G.; LAMEGO, F. P.; Proporção entre plantas de soja e plantas competidoras e as relações de interferência mútua. Ciência Rural, 36: 1380-1387, 2006.

COSTA, L. O.; RIZZARDI, M. A. Competitive ability of wheat in association with biotypes of Raphanus raphanistrum L. resistant and susceptible to ALS-inhibitor herbicides. Ciência e Agrotecnologia, 39: 121-130, 2015.

COUSENS, R.; O’NEILL, M. Density dependence of replacement series experiments. Oikos, 66: 347352,1993

COUSENS, R. Aspects of the design and interpretation of competition (interference) experiments. Weed Tecnology, 5: 664-673, 1991.

EMBRAPA - Empresa Brasileira de Pesquisa Agropecuária. Centro Nacional de Pesquisa Agropecuária de Solos (Brasília, DF). Sistema brasileiro de classificação de solos. Brasília, DF: Embrapa Produção de Informação; Brasília, DF: Embrapa Solos, 2013. 154 p

FARIA, R. M.; BARROS, R. E.; TUFFI SANTOS L. D. Weed interference on growth and yield of transgenic maize. Planta Daninha, 32: 515-520, 2014.

FLECK, N. G. et al. Competitividade relativa entre cultivares de arroz irrigado e biótipo de arrozvermelho. Planta Daninha, 26: 101-111, 2008.

FORTE, C. T. et al. Habilidade competitiva de cultivares de soja transgênica convivendo com plantas daninhas. Revista Brasileira de Ciências 
Agrárias, 12: 185-193, 2017.

FRANDOLOSO, F. et al. Competition of maize hybrids with alexandergrass (Urochloa plantaginea). Australian Journal of Crop Science, 13: 14471455, 2019.

GALON, L. et al. Competitive interaction and economic injury level of Urochloa plantaginea in corn hybrids. Arquivos do Instituto Biológico, 86: e0182019, 2019.

GALON, L. et al. Competição entre híbridos de milho com plantas daninhas. South American Sciences, 2: e21101, 2021.

HEAP, I. Weed Science. International Survey Of Herbicide Resistant Weeds. Disponível em: http:// www.weedscience.org/Summary/Country.aspx? Acesso em: 03 abr. 2020.

HOFFMAN, M. L.; BUHLER, D. D. Utilizing Sorghum as a functional model of crop weed competition. I. Establishing a competitive hierarchy. Weed Science, 50: 466-472, 2002.

MARIANI, F. et al. Valor adaptativo e habilidade competitiva de azevém resistente e suscetível ao iodosulfuron em competição com o trigo. Pesquisa Agropecuária Brasileira, 51: 710-719, 2016.

MEROTTO JR., A.; FISCHER, A. J.; VIDAL, R. A. Perspectivas da utilização da qualidade da luz como uma avançada ferramenta ecofisiológica para o manejo de plantas daninhas. Planta Daninha, 27: 407-419, 2009.

MORAES, P. V. D. et al. Manejo de plantas de cobertura no controle de plantas daninhas e desempenho produtivo da cultura do milho. Semina: Ciências Agrárias, 34: 497-508, 2013.

RUBIN, R. S. et al. Relative competitive ability of irrigated rice with red rice susceptible or resistant to the herbicide imazapyr + imazapic. Arquivos do Instituto Biológico, 81: 173-179, 2014.

SILVA, L. S. et al. Manual de calagem e adubação para os estados do Rio Grande do Sul e de Santa Catarina. 11. ed. Porto Alegre, RS: Sociedade Brasileira de Ciência do Solo - Núcleo Regional Sul: Comissão de Química e Fertilidade do Solo - RS/ SC, 2016. 376 p.

SCHAEDLER, C. E. et al. Globe fringerush (Fimbristylis miliacea) cross resistance to alsinhibitor herbicides under field conditions in irrigated rice in the south of Brazil. Planta Daninha,

\section{1: 893-902, 2013}

TREZZI, M. M. et al. Bioensaios para identificação de biótipos de Euphorbia heterophylla com resistência múltipla a inibidores da ALS e da PROTOX. Planta Daninha, 24: 563-571, 2006.

VARGAS, L. et al. Práticas de manejo e a resistência de Euphorbia heterophylla aos inibidores da ALS e tolerância ao glyphosate no Rio Grande do Sul. Planta Daninha, 31: 427-432, 2013.

VAZIN, F. The effects of pigweed redroot (Amaranthus retoflexus) weed competition and its economic thresholds in corn (Zea mays). Planta Daninha, 30: 477-485, 2012.

WANDSCHEER, A. C. D. et al. Capacidade competitiva da cultura do milho em relação ao capim -sudão. Revista Brasileira de Milho Sorgo, 13: 129 $-141,2014$.

WANDSCHEER, A. C. D.; RIZZARDI, M. A.; REICHERT, M. Competitive ability of corn in coexistence with goosegrass. Planta Daninha, 31: 281-289, 2013.

WU, W. et al. Sensitivity analysis of crop growth models to multi-temporal scale solar radiation. Transactions of the Chinese Society of Agricultural Engineering, 28: 123-128, 2012.

ZANINE, A. M.; SANTOS, E. M. Competition among species of plants - A review. Revista da Faculdade de Zootecnia, Veterinária e Agronomia, 11: 10-30, 2004. 